\title{
МОРФОЛОГИЧЕСКИЕ ОСОБЕННОСТИ В- И А-КЛЕТОК ПОДЖЕЛУДОЧНОЙ ЖЕЛЕЗЫ ВОЗРАСТНЫХ КРЫС С САХАРНЫМ ДИАБЕТОМ 2 ТИПА ПРИ ДЛИТЕЛЬНОЙ ТЕРАПИИ РАЗЛИЧНЫМИ ПРЕПАРАТАМИ СУЛЬФОНИЛМОЧЕВИНЫ
}

\author{
' Тучина Т.П., ' Скотникова К.П., ${ }^{2}$ Вторушина А.А., ' Рогоза О.В., ' Грозов Р.В., ' Бабенко А.Ю., 1 Галагудза М.М. \\ 'ФГБУ «Национальный медицинский исследовательский центр имени В. А. Алмазова» Минздрава России, Санкт- \\ Петербург \\ 2ФГБОУ ВО «Первый Санкт-Петербургский государственный медицинский университет им. акад. И.П.Павлова» \\ Минздрава России, Санкт-Петербург
}

По данным Федерального регистра сахарного диабета более 50\% пациентов с сахарным диабетом 2 типа (СД2) в РФ получают препараты сульфонилмочевины(ПСМ). Существуют данные, что прием ПСМ способствует развитию $\beta$-клеточной недостаточности, а также приводит к усилению глюкагонового ответа и гиперплазии а-клеток. Однако, результаты проводимых в мире исследований по данной тематике весьма противоречивы и зависят от многих факторов. Известно, что с возрастом и у людей без СД2 происходит уменьшение количества $\beta$-клеток и гиперплазия а-клеток, что затрудняет клиническую оценку вклада терапии ПСМ в этой группе.

ЦЕЛЬ: целью настоящего исследования стало сравнение влияния длительного введения различных ПСМ (Глибенкламида и Гликлазида) на морфологический состав поджелудочной железы (суммарный объем(СО) а и $\beta$ клеток поджелудочной железы) и экспрессию маркеров пролиферации, апоптоза при экспериментальном СД2 у возрастных животных.

МАТЕРИАЛЫ И МЕТОДЫ: в эксперимент включались белые крысы самцы ( $\mathrm{n}=30)$. По достижению животными возраста 12 месяцев, моделировался стрептозотоцин-никотинамид индуцированный СД2. СД2 диагностировался через одну неделю после моделирования по результатам глюкозотолерантного теста. В течение 4 недель после индукции сахарного диабета крысы содержались без терапии, после чего получали препараты согласно сформированным группам в течение 24 недель. Дозы препаратов высчитывали сучетом среднетерапевтической дозировки для пациентов с использованием коэффициента перерасчета на крысу.

1. Группа интактных животных

2. Группа с СД2 без терапии

3. Группа с СД2 на терапии Гликлазидом

4. Группа с СД2 на терапии Глибенкламидом

В дальнейшем проводилось иммуногистохимическое исследование с применением антител к инсулину, глюкагону, маркеру пролиферации Ki-67, маркеру апоптоза р53.

PEЗУЛЬTATЫ: CO а-клеток у животных группы СД2 без терапии был значимо больше, чем в у группы интактных животных, а СО $\beta$-клеток - значимо меньше (p<0,05). К 24й неделе эксперимента у животных, получающих Глибенкламид СО а-клеток к площади островка поджелудочной железы не изменился по сравнению с группой животных с СД2 без терапии $(p=0,75)$. У животных, получавших Гликлазид было отмечено статистически значимое уменьшение количества а-клеток ( $p=0.000004)$, которое стало сопоставимым с таковым в группе интактных животных $(\mathrm{p}=0,85)$. СО $\beta$-клеток не изменился ни в одной из терапевтических групп ( $p=0.39$ ). При оценке динамики Ki-67, p53 ни в одной из исследованных групп не было отмечено значимых изменений.

ВЫВОД: у возрастных животных с СД2 отмечается увеличение количества а-клеток и уменьшение количества $\beta$-клеток по сравнению с интактными животными того же возраста. Длительная терапия ПСМ не оказывала влияния на СО $\beta$-клеток у крыс с СД2, который оставался на том же уровне, что и у группы с СД2 без терапии. На терапии Гликлазидом в течение 24 недель отмечалась нормализация СО а-клеток, в то время как на терапии Глибенкламидом сохранялась гиперплазия а-клеток. Изменение количества как $\beta$-, так и а-клеток не является следствием изменения активности пролиферации или апоптоза.

КЛЮЧЕВЫЕ СЛОВА: сахарный диабет 2 munа; препараты сульфонилмочевины; а- и $\beta$-клетки поджелудочной железы. 